\title{
Pengaruh Field Trip Mangrove Cagar Alam Pulau Dua terhadap Sikap Ilmiah Siswa SMA
}

\author{
Dwi Ratnasari ${ }^{1}$, RR Hertien Koosbandiah ${ }^{2)}$ dan Bambang Supriatno ${ }^{3)}$ \\ ${ }^{1)}$ Jurusan Pendidikan Biologi, FKIP, Universitas Sultan Ageng Tirtayasa \\ ${ }^{2)}$ Pendidikan Biologi, Pascasarjana, Universitas Pendidikan Indonesia \\ ${ }^{3)}$ Pendidikan Biologi, Pascasarjana, Universitas Pendidikan Indonesia \\ dwiratnasari@untirta.ac.id
}

\begin{abstract}
The aims of this study was to determine the effect of field trip Mangrove Pulau Dua Nature Reserve on the scientific attitude of high school students. The research method is used quasi experiment. On the design using two classes, experimental class and control class. The population is used the students of grade X SMA Negeri A Kota Serang. Data were obtained from a scientific attitude questionnaire calculated using MSI (Methode of Successive Interval) and a questionnaire of teacher and student responses regarding the implementation of learning. The results showed that there was no significant difference of scientific attitude between the experimental class and the control class.
\end{abstract}

Keywords : Field trip, Pulau Dua Nature Reserve, Scientific attitude

This is an open access article distributed under the Creative Commons 4.0 Attribution License, which permits unrestricted use, distribution, and reproduction in any medium, provided the original work is properly cited $\odot 2018$ by author and Universitas Negeri Padang.

\section{PENDAHULUAN}

Belajar merupakan suatu proses yang kompleks yang dialami pada diri setiap manusia sepanjang hayatnya. Proses belajar dapat terjadi karena adanya interaksi antara seseorang dengan lingkungan, baik lingkungan sosial maupun lingkungan alam sekitar. Kegiatan belajar akan optimal jika siswa terlibat langsung dalam proses pembelajaran. Sesuai dengan teori penemuan Bruner (Dahar, 2011) siswa-siswa sebaiknya belajar melalui partisipasi secara aktif agar mereka memperoleh pengalaman dan menemukan sebuah prinsip. Biologi merupakan salah satu ilmu sains yang dalam proses pembelajarannya memerlukan interaksi lang sung dengan lingkungan sekitar.

Pemanfaatan potensi lokal dengan meng amati objek secara langsung seyogianya dapat membantu siswa dalam memahami mata pelajaran biologi, khususnya mengenai pencemaran lingkungan. Salah satu potensi lokal yang dapat dimanfaatkan siswa adalah Cagar Alam Pulau Dua. Cagar Alam Pulau Dua merupakan kawasan konservasi wilayah Balai Besar Konservasi Sumber Daya Alam (BBKSDA) Jawa Barat dengan ciri khas ekosistem mangrove dan burung-burung air baik migran maupun lokal. Cagar Alam Pulau Dua sudah mengalami perubahan yang disebabkan oleh alam dan aktivitas manusia (Takandjandji, 2010). Ancaman yang sangat mengganggu kehidupan dan habitat spesies di ekosistem mangrove, antara lain adalah abrasi, perburuan, pencarian kayu bakar dan sampah rumah tangga yang berserakan yang dapat menyebabkan menurunnya kualitas serta kuantitas habitat tumbuhan dan satwa liar. Menurut Surtikanti (2012) ekosistem mangrove menawarkan banyak manfaat kepada manusia sehingga keberadaannya rentan dari perusakan bahkan pemusnahan oleh manusia. Faktor lain yang dapat menyebabkan ketidakseimbangan ling kungan adalah semakin berkembangnya kecang gihan teknologi yang tidak diimbangi oleh kesadaran masyarakat akan dampak negatif yang dapat ditimbulkannya. Adanya kemajuan di bidang ilmu pengetahuan dan teknologi tidak terlepas dari perubahan lingkungan sehingga menyebabkan ketidakseimbangan lingkungan (Yulianti \& Martuti, 2015)

SMA Negeri A kota Serang-Banten merupakan sekolah yang lokasinya dekat dengan Cagar Alam Pulau Dua. Namun, siswa di sekolah tersebut belum pernah melihat keadaan mangrove secara langsung. Siswa perlu mengetahui perubahan dan pencemaran lingkungan yang terjadi di sana sebagai bahan kajian mengenai faktor-faktor penyebab serta akibat yang ditimbulkan dari pencemaran dan kerusakan lingkungan melalui interaksi lang sung dengan objeknya. Siswa diharapkan dapat dengan mudah memahami materi yang telah 
dipelajari dan memiliki sikap yang lebih peduli terhadap lingkungan sekitar. Sikap-sikap tersebut, merupakan nilai-nilai karakter yang ingin dikembangkan dalam proses pembelajaran. Slameto (2010) menyatakan bahwa sikap merupakan salah satu faktor yang dapat mempengaruhi hasil belajar dan prestasi belajar siswa. Sikap ilmiah ini merupakan perwujudan nilai-nilai karakter yang diimplementasikan dalam pembelajaran sains (Riyanto, 2013).

Proses pembelajaran dapat dilakukan melalui field trip pada mangrove Cagar Alam Pulau Dua. Field trip dapat membantu siswa dalam memperoleh pengalaman nyata secara langsung sehingga siswa dapat mengaitkan pengetahuan yang telah dimiliki dengan keadaan yang terjadi sesungguhnya. Field trip merupa kan cara belajar dengan membawa siswa ke suatu tempat atau objek di luar sekolah untuk mempelajari dan memperdalam pelajarannya dengan melihat kenyataan secara langsung agar pembelajaran lebih relevan (Djamarah \& Zain, 2013).

Melalui proses atau langkah-langkah sains, siswa mampu membangun "satu set" sikap ilmiah yang meliputi rasa ingin tahu, ketekunan, ketelitian, kejujuran, keterbukaan, di samping berbagai scientific skill. Menurut Kemendikbud (2014) untuk memperoleh hasil belajar yang nyata dan otentik, peserta didik harus mencoba atau melakukan percobaan terutama untuk materi atau subtansi yang sesuai, serta harus memiliki keterampilan proses untuk mengembangkan pengetahuan tentang alam sekitar, mampu menggunakan metode ilmiah dan bersikap ilmiah untuk memecahkan masalah-masalah yang dihadapinya dalam kehidupan sehari-hari. Oleh karena itu perlu dilakukan penelitian mengenai: "Pengaruh Field Trip Mangrove Cagar Alam Pulau Dua Terhadap Sikap Ilmiah Siswa SMA"

\section{METODE PENELITIAN}

Metode penelitian yang digunakan adalah metode quasi eksperimen dengan desain penelitian The Matching - Posttest Only Control Group Design. Pada subjek penelitian tidak dilakukan tes awal (pretest) karena kelas yang dipilih sudah homogen. Populasi yang digunakan adalah siswa kelas X SMA Negeri A Kota Serang. Pada desain menggunakan dua kelas, yaitu kelas kontrol yang melakukan kegiatan pembelajaran tentang pencemaran lingkungan di dalam kelas dengan metode ceramah dan diskusi, sedangkan kelas eksperimen melakukan kegiatan pembelajaran melalui kegiatan field trip mangrove Cagar Alam Pulau Dua. Sampel kelas yang digunakan ditentukan secara purposive sampling.

Sikap ilmiah merupakan kecenderungan tingkah laku seseorang dalam merespon permasalahan-permasalahan ilmiah. Sikap ilmiah diamati dari skala sikap siswa yang positif maupun negatif terhadap pembelajaran biologi. Sikap ilmiah siswa dijaring melalui angket yang berisi sejumlah pernyataan yang bersesuaian dengan indikator sikap ilmiah (sikap ingin tahu, sikap respek terhadap fakta, sikap berpikir kritis, sikap berpikiran terbuka dan kerjasama, dan sikap peka terhadap lingkungan) dengan menggunakan skala Likert. Skala tersebut meliputi: sangat setuju (SS), setuju (S), tidak setuju (TS), dan sangat tidak setuju (STS). Selain data dari angket sikap ilmiah, data juga diperoleh dari angket tanggapan guru biologi dan siswa mengenai pembelajaran yang dilaku kan dengan metode field trip yang dilakukan dengan memanfaatkan mangrove Cagar Alam Pulau Dua. Angket tanggapan dinyatakan dalam dua kategori jawaban, yaitu ya atau tidak yang disertai dengan alasan dari jawaban tersebut.

Penelitian dilakukan melalui tahap per siapan, tahap pelaksanaan, dan tahap pengolahan serta analisis data. Analisis data sikap ilmiah dilakukan melalui uji normalitas, homogenitas dan tahap menguji hipotesis penelitian. Perhitungan skor sikap ilmiah dilakukan dengan menggunakan metode suksesif interval (Method of Successive Interval atau MSI) untuk meng ubah data ordinal pada angket menjadi data interval. Data angket tanggapan guru dan siswa dihitung dan dianalisis berdasarkan persentase jawaban positif dan negatif yang diberikan oleh guru dan siswa.

\section{HASIL DAN PEMBAHASAN}

\section{Hasil Penelitian}

Sikap ilmiah siswa diukur melalui angket sikap ilmiah dan angket tanggapan guru serta siswa mengenai pembelajaran dengan metode field trip. Angket sikap ilmiah dan angket tanggapan guru serta siswa diberikan setelah siswa melakukan kegiatan field trip untuk kelas eksperimen, sedangkan untuk kelas kontrol angket diberikan setelah siswa selesai pembelajaran di dalam kelas. Data angket sikap 
ilmiah dihitung dengan perhitungan MSI (Methode of Successive Interval) untuk mengubah data ordinal menjadi data interval lalu dihitung normalitas, homogenitas, dan uji-t. Data angket tanggapan guru dan siswa dihitung dan dianalisis berdasarkan persentase jawaban positif dan negatif guru dan siswa yang disertai alasannya. Berikut ini merupakan data hasil analisis angket sikap ilmiah kelas eksperimen dan kelas kontrol dengan perhitungan MSI:

\section{IKelas Eksperimen IKelas Kontrol}

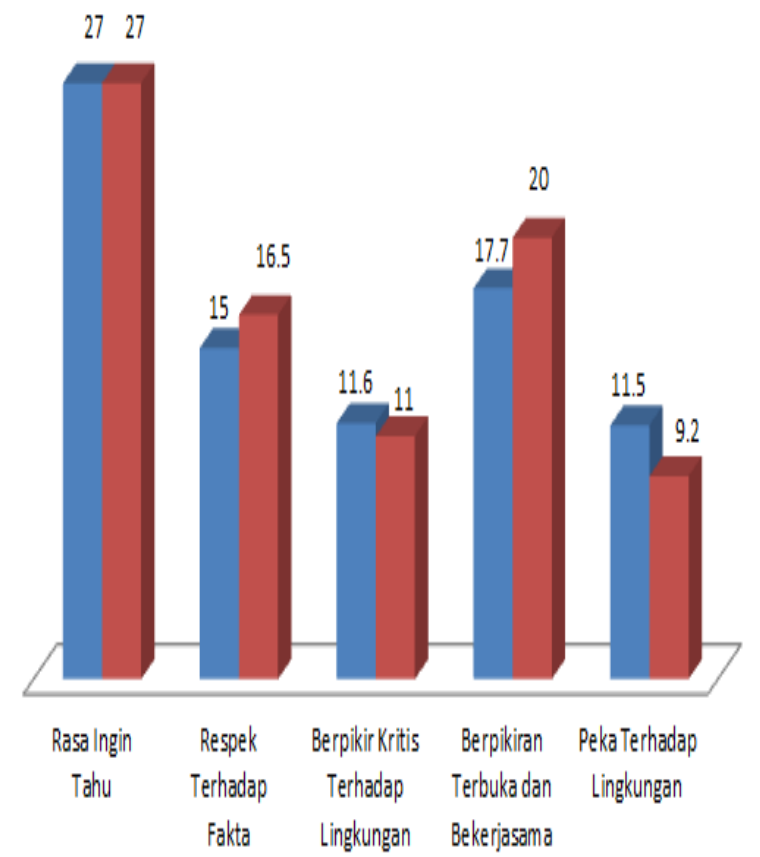

Gambar 1. Skor Angket Sikap Ilmiah Siswa Kelas Eksperimen dan Kelas Kontrol

Hasil perhitungan uji normalitas diperoleh bahwa nilai signifikansi (Asymp. Sig 2-tailed) kelas eksperimen adalah 0,949 dan kelas kontrol sebesar 0,084 nilai keduanya lebih besar dari $\alpha=$ 0,05 sehingga $\mathrm{H}_{0}$ diterima yang berarti bahwa data berdistribusi normal. Hasil perhitungan homogenitas diperoleh data $\mathrm{P}$-value= sig. 0,681 yang berarti data homogen. Hasil uji statistik ttest menunjukkan bahwa uji $\mathrm{t}$ hitung $(0.264)<\mathrm{t}$ tabel (31;0,025 adalah 2.040), dengan signifikansi Sig (2-tailed) $(0,792)<(0,025)$ maka $\mathrm{H}_{0}$ diterima. Jadi antara kelas eksperimen dan kelas kontrol menunjukkan tidak ada perbedaan nilai yang signifikan. Nilai sikap ilmiah siswa yang belajar menggunakan metode field trip sama dengan nilai sikap ilmiah siswa pada kelas yang belajar dengan metode ceramah dan diskusi.

\section{Pembahasan}

Pada analisis hasil sikap ilmiah tidak terdapat perbedaan nilai yang signifikan antara kelas eksperimen dengan kelas kontrol. Berdasarkan Gambar 1 dapat dilihat bahwa pada kelas eksperimen dan kelas kontrol sikap ilmiah yang muncul tertinggi adalah rasa ingin tahu siswa.

Setelah dihitung dengan MSI (Methode of Successive Interval) nilai rata-rata tertinggi sikap ilmiah pada kelas eksperimen dan kelas kontrol adalah pada indikator rasa ingin tahu. 'To be scientific mean that one has such attitudes as curiosity, rationality, willingness to suspend judgment, open mindedness, critical mindedness, objectivity, honesty and humility etc. attitude regulate behavior that is directed towards or away from some object or situation group of objects or situations' (Pitafi, 2012).

Rasa ingin tahu yang tinggi pada kedua kelas memiliki rata-rata yang tinggi dibanding kan dengan indikator sikap ilmiah yang lainnya. Hal ini dapat dikarenakan tingginya rasa ingin tahu siswa pada kedua kelas mengenai berbagai macam masalah tentang pencemaran, penyebab pencemaran dan akibat yang ditimbulkan dari pencemaran yang terjadi di lingkungan sekitar. Siswa harus menjadi pelajar sepanjang hayat yang selalu memiliki keinginan untuk mencari, meneliti, dan menggunakan informasi dengan kesadaran sendiri (Komalasari, 2011).

Pada kelas kontrol rasa ingin tahu yang tinggi dapat disebabkan karena rasa keingin tahuan atau penasaran yang muncul mengenai keadaan mangrove Cagar Alam Pulau Dua. Siswa tidak melakukan pengamatan langsung di lokasi sehingga siswa hanya dapat memperkira kan keadaan mangrove yang alami dan tercemar. Hal ini dapat dilihat dari hasil angket tanggapan siswa yang menyatakan bahwa mereka belum pernah melakukan kunjungan lapangan ke Cagar Alam Pulau Dua sehingga ingin sekali ke sana untuk melihat keadaan mangrove dan ekosistem di sana. Siswa pada kelas eksperimen memiliki rasa ingin tahu yang tinggi karena siswa mengalami kegiatan pembelajaran langsung di Cagar Alam Pulau Dua sehingga ketika di lokasi siswa semakin ingin mengetahui, melihat, mengamati dan menjawab berbagai pertanyaan yang muncul dipikirannya mengenai keadaan mangrove yang masih alami dan sudah tercemar saat sebelum mengunjungi Cagar Alam Pulau Dua. Pada hakekatnya siswa memiliki rasa keingintahuan yang tinggi hal ini perlu 
dimanfaatkan guru untuk memotivasi siswa untuk mengajukan pertanyaan (Natalina, et al, 2013).

Pada kelas eksperimen dan kelas kontrol berpikiran terbuka dan bekerjasama memiliki nilai rata-rata tertinggi kedua setelah rasa ingin tahu. 'Experience that foster open-mindedness includes those in which pupils are confronted with the needs to revise a belief the result of having acquired new information on the subject' (Pitafi, 2012). Hal ini dapat disebabkan oleh kegiatan belajar yang sedang dilakukan oleh siswa. Sikap berpikiran terbuka merupakan salah satu cara membuka pikiran siswa, semakin banyak pengetahuan yang telah diperoleh siswa maka akan semakin siswa menyadari bahwa banyak pengetahuan atau informasi yang belum diketahui oleh siswa. Sikap berpikiran terbuka ini terkait dengan rasa ingin tahu siswa. Semakin banyak pengetahuan yang dimiliki siswa semakin tinggi juga rasa ingin tahunya. Pada kelas eksperimen, rasa ingin tahu yang tinggi mendorong siswa untuk mencari informasi lebih banyak mengenai gejala alam dan temuan-temuan yang baru saja diperolehnya di mangrove Cagar Alam Pulau Dua. Siswa pada kelas kontrol, rasa ingin tahu yang tinggi diikuti dengan keinginannya untuk terus membuka pikiran mengenai pencemaran lingkungan agar memperoleh informasi lebih banyak bukan hanya sekedar dari buku dan penjelasan guru semata.

Pada kelas kontrol siswa selain mengguna kan metode ceramah oleh guru, siswa juga melakukan kegiatan diskusi antar kelompok. Siswa dibagi menjadi 6 kelompok, kemudian diminta untuk mencari masalah pencemaran yang terjadi di lingkungan sekitar untuk dibahas dan didiskusikan dengan kelompok kemudian dipresentasikan di depan kelas. Kegiatan belajar ini dapat memunculkan sikap berpikiran terbuka terhadap keadaan lingkungan dan bekerjasama antar teman kelompok. Siswa bersama dengan teman sekolompoknya mencari informasi terkini sebanyak mungkin mengenai pencemaran lingkungan. Adanya kegiatan diskusi ini secara tidak langsung membuat siswa saling membantu dan mencoba bersama-sama untuk menyelesai kan permasalahan-permasalahan yang ada.

Pada kelas eksperimen, siswa diajak melihat langsung keadaan mangrove sehingga muncul informasi baru yang diamati dan diperoleh oleh siswa. Selain itu selama kegiatan field trip siswa melaksanakan tugas secara berkelompok, dari mulai awal pengamatan hingga akhir pengamatan. Kerjasama yang baik dilihat dari hasil observasi pada saat siswa melakukan perjalanan ke dalam hutan mangrove, kondisi tanah yang berlumpur, berair, berbatuan, dan berduri membuat siswa saling membantu untuk dapat melewati dan memasuki hutan dengan mudah sehingga pengamatan dapat berjalan dengan baik. Hal ini juga dapat dilihat dari hasil angket tanggapan siswa bahwa siswa menyatakan Cagar Alam Pulau Dua dapat digunakan sebagai sumber belajar yang terjangkau dari segi keamanan karena mereka bisa saling bekerjasama dengan teman kelompok. Pengalaman bekerjasama tidak hanya membantu siswa belajar menguasai materi pembelajaran, tetapi juga sekaligus memberikan wawasan pada dunia nyata bahwa untuk menyelesaikan suatu tugas akan lebih berhasil jika dilakukan secara bersama-sama atau kerja sama dalam bentuk tim (Komalasari, 2011).

Pada kelas eksperimen dan kelas kontrol, indikator respek terhadap fakta memiliki nilai rata-rata tertinggi setelah berpikiran terbuka dan bekerjasama. Memberi motivasi belajar dengan lingkungan kepada siswa dapat mengembangkan pola pikir, keterampilan, dan sikap siswa lebih nyata dan fungsional (Supriadie, 2012). Pada kelas kontrol sikap ini muncul ketika siswa mencari berbagai informasi mengenai pencemar an yang terjadi di lingkungan sekitar dan pada saat siswa melakukan tanya jawab mengenai masalah yang dipaparkan oleh teman kelompok lainnya. Pada kelas eksperimen sikap respek terhadap fakta ini muncul ketika siswa mengamati berbagai komponen biotik dan abiotik yang ada pada kedua daerah pengamatan (alami dan tercemar), siswa bertanya dan mengamati perbedaan antara kedua daerah pengamatan. Siswa mengamati perbedaan komponen biotik yang ada pada daerah alami dan tercemar dan siswa mulai mengetahui mengapa perbedaan itu terjadi karena adanya beberapa faktor penyebab yang ditimbulkan oleh bahan pencemar.

Pada kelas kontrol dan kelas eksperimen, berpikir kritis terhadap lingkungan memiliki nilai rata-rata setelah bersikap respek terhadap fakta.'A person with critical minded attitude looks for evidence and arguments that support other persons assertion' (Pitafi, 2012). Pada eksperimen siswa melihat langsung keadaan yang terjadi ketika suatu lingkungan mengalami pencemaran, sehingga siswa lebih kritis 
terhadap keadaan tersebut. Siswa menjadi lebih memahami bahwa kegiatan pencemaran yang dilakukan manusia sangat berpengaruh terhadap lingkungannya sendiri. Pada kelas kontrol siswa lebih mengkritisi dan mengomentari masalahmasalah pencemaran yang terjadi melalui metode diskusi dan tanya jawab antar siswa di dalam kelas.

Sikap peka terhadap lingkungan merupa kan indikator terendah pada kedua kelas. Rendahnya sikap peka terhadap lingkungan pada kelas kontrol dapat dikarenakan siswa belum mengetahui secara langsung salah satu contoh lingkungan yang mengalami pencemaran, apa penyebab dan akibatnya terhadap lingkungan, sehingga siswa masih merasa acuh dan kurang peduli terhadap masalah lingkungan. Sikap peka terhadap lingkungan pada eksperimen juga rendah. Namun jika dibandingkan dengan kelas kontrol siswa pada kelas eksperimen mulai belajar tentang pentingnya menjaga lingkungan. Sikap peka terhadap lingkungan terbentuk ketika siswa melihat fakta tercemarnya lingkungan. Sikap peduli lingkungan dapat muncul pada saat siswa diajak untuk belajar bersikap peduli terhadap lingkungan (Saptono, 2011).

Salah satu bentuk kepekaan siswa dalam menjaga lingkungan adalah ditunjukkan dengan kegiatan membawa sampah-sampah anorganik rumah tangga yang berserakan di sepanjang jalan hutan mangrove. Siswa membawa sampahsampah tersebut dalam kantong besar dan mengumpulkannya untuk dibuang pada tempat pembuangan sampah. Selain itu sikap kepekaan juga ditunjukkan oleh siswa dalam menanam mangrove. Siswa dilatih oleh penjaga kawasan Cagar Alam Pulau Dua untuk menanam mangrove pada wilayah yang telah ditentu kan. 'Because of the term, "environment" is very important for all, so the teachers' and the parents' roles must be to educate children as a good environment protectors in the lessons and at their special lives' (Barlas, 2013). Lingkung an sangat penting bagi semua, oleh karenanya para guru dan orangtua harus mendidik anakanak agar menjadi penjaga lingkungan yang baik dalam pembelajaran dan dalam kehidupannya.

Selain dari hasil angket, sikap siswa pada kelas eksperimen dari awal kegiatan hingga saat pelaksanaan kegiatan field trip diamati oleh observer. Pengamatan dilakukan berdasarkan indikator-indikator sikap ilmiah. Pada indikator rasa ingin tahu diamati bahwa pada tahap persiapan pembelajaran sebagian besar siswa memperhatikan penjelasan mengenai prosedur pelaksanaan kegiatan field trip mangrove Cagar Alam Pulau Dua. Siswa sangat antusias menanyakan setiap langkah kerja yang akan dilakukan pada saat field trip mangrove Cagar Alam Pulau Dua. Pada indikator respek terhadap fakta, siswa berusaha untuk melaksanakan kegiatan field trip dengan sungguh-sungguh dan tidak memanipulasi data-data yang diperolehnya dalam pengamatan. Pada indikator berpikir kritis terhadap fakta, sebagian besar siswa menanya kan perubahan kondisi yang terjadi pada mangrove alami dan tercemar sehingga dengan sendirinya siswa mampu menemukan cara untuk menjawab dan menyelesaikan masalahnya. Pada indikator berpikiran terbuka dan bekerja sama siswa saling menerima pendapat dan saran yang disampaikan oleh teman sekelompoknya ketika menjawab pertanyaan-pertanyaan dalam lembar kerja, siswa saling bekerja sama ketika dalam perjalanan siswa menemui medan yang berair, berlumpur, berbatu, dan licin sehingga teman kelompok dan semua siswa dalam keadaan aman. Prinsip kerja sama pada siswa dilakukan agar siswa saling membantu, menghindarkan rasa keangkuhan, menyadarkan siswa bahwa tidak semua hal dapat dikerjakan sendiri, dan untuk mengembangkan suasana saling mem belajarkan di antara siswa (Supriadie, 2012). Pada indikator peka terhadap lingkungan, siswa saling menjaga kebersihan selama kegiatan field trip, siswa mengambil sampah-sampah yang berserakan di sepanjang perjalanan pulang dari field trip, selain itu sikap peka terhadap lingkungan juga dilihat dari sikap siswa dalam membantu menanam bibit mangrove yang telah disediakan dengan petunjuk penanaman yang dilakukan oleh pemandu mangrove Cagar Alam Pulau Dua.

Berdasarkan hasil analisis angket tanggap an siswa dan guru diperoleh tanggapan yang positif mengenai kegiatan pembelajaran pen cemaran lingkungan melalui kegiatan field trip pada mangrove Cagar Alam Pulau Dua. Hasil angket menunjukkan bahwa siswa pada kelas eksperimen dan kelas kontrol pernah melakukan pembelajaran di luar kelas pada beberapa materi biologi, namun siswa belum pernah mengguna kan metode kunjungan lapangan (field trip) ke mangrove Cagar Alam Pulau Dua saat mem pelajari materi pencemaran lingkungan.

Siswa sangat antusias dan minat siswa terlihat tinggi untuk mengikuti kegiatan field 
trip. Siswa pada kelas kontrol hanya sebagian besar yang menganggap mangrove Cagar Alam Pulau Dua dapat dijadikan sebagai sumber belajar. Hal ini dapat dikarenakan siswa belum melihat langsung bagaimana keadaan di sana dan apa saja yang terdapat pada ekosistem mangrove sehingga siswa kurang sependapat bahwa kawasan Cagar Alam Pulau Dua dapat dijadikan sumber balajar pada konsep pencemaran lingkungan. Lain halnya dengan siswa pada kelas eksperimen yang telah melaksanakan kegiatan field trip, siswa merasa bahwa Cagar Alam Pulau Dua dapat dijadikan sebagai sumber belajar bagi siswa dalam mempelajari pencemaran lingkungan karena di sana terdapat keanekaragaman tumbuhan dan hewan yang jumlah dan karakteristiknya berbeda pada mangrove yang masih alami dan tercemar. Banyak gejala alam dan fakta-fakta lainnya yang menjadi pengetahuan baru bagi siswa saat melakukan kegiatan field trip disana. Siswa merasa lebih mudah memahami konsep pencemaran lingkungan dibandingkan dengan pembelajaran dengan metode ceramah di dalam kelas. Metode kunjungan lapangan mahasiswa mampu memperdalam pemahaman tentang teori dan praktek yang dipelajari di kelas melalui pengalaman langsung berinteraksi dengan alam (Wulandari, 2016).

Seiring dengan pelaksanaan kegiatan field trip sikap ilmiah pada siswa terbentuk. Salah satu sikap ilmiah yang terbentuk pada siswa adalah rasa ingin tahu yang tinggi pada keadaan mangrove yang masih alami dan tercemar, sikap keterbukaan dan bekerjasama antar teman kelompok dalam pelaksanaan selama perjalanan field trip. Pembelajaran dengan cara melihat langsung kondisi nyata dan fenomena alam nyata di bantaran Sungai Tayu dapat mempermudah siswa dalam memahami materi, memberikan pengalaman yang lebih, serta dapat menggugah siswa untuk bertindak lebih peduli dengan lingkungan, baik lingkungan sosial maupun alam (Yulianti \& Martuti, 2015).

Menurut guru bidang biologi yang mengajar siswa pada kelas eksperimen dan kelas kontrol juga memberikan tanggapan positif mengenai kegiatan field trip pada Cagar Alam Pulau Dua. Guru menyatakan bahwa pernah mengajak siswa untuk belajar di luar ruangan kelas, namun belum pernah untuk mengajak siswa kunjungan lapangan. Guru hanya melakukan pembelajaran langsung sebatas belajar di luar kelas, seperti saat praktikum di laboratorium dan kegiatan observasi di sekeliling sekolah saja. Guru menanggapi bahwa mangrove Cagar Alam Pulau Dua dapat dijadikan sebagai sumber belajar karena beliau dapat dengan mudah menjelaskan fenomenafenomena pencemaran yang terjadi di lingkung an karena di sana terlihat nyata perbedaan keadaan lingkungan mangrove yang masih alami dan tercemar. Metode karyawisata merupakan metode yang mengajak siswa ke objek tertentu untuk mempelajari sesuatu sehingga berguna bagi siswa dalam mengenai kehidupan riil beserta segala masalah yang ada di dalamnya (Suyatno \& Jihat, 2013). Adanya fakta-fakta dan gejala alam yang terjadi di ekosistem mangrove, dapat membantu siswa dalam memahami konsep pencemaran lingkungan menjadi lebih mudah. Karya wisata dapat memberikan pengalaman nyata dan belajar dengan konteks melalui sumber belajar di tempat yang dikunjungi (Supriadie, 2012). Siswa terlihat sangat antusias dan semangat ketika tahap persiapan dan tahap pelaksanan kegiatan field trip.

Kegiatan field trip juga dapat membuat siswa memiliki sikap ilmiah. Adanya fakta-fakta dan gejala alam yang siswa lihat dan amati pada mangrove Cagar Alam Pulau Dua, memuncul kan banyak pertanyaan dan rasa ingin tahu yang tinggi terhadap fakta-fakta dan gejala alam yang siswa lihat selama kegiatan field trip. Sikap ilmiah terbentuk karena siswa secara langsung melihat keadaan mangrove yang tercemar dan dampak dari pencemarannya dapat siswa lihat sendiri sehingga rasa ingin tahu siswa mengenai permasalahan pencemaran lingkungan dapat terjawab selama siswa melakukan pengamatan pada mangrove Cagar Alam Pulau Dua yang mengalami pencemaran.

Pembelajaran secara langsung dengan metode field trip yang memperlihatkan secara nyata terjadinya pencemaran membuat siswa merasa betapa pentingnya menjaga lingkungan sekitar sehingga rasa kepedulian siswa terhadap lingkungan sekitar terbentuk. Menurut Kemen diknas (2010) peduli lingkungan merupakan salah satu bentuk nilai karakter. Sikap peduli lingkungan penting dipelajari dan dipahami oleh siswa untuk mencegah berbagai macam kerusak an lingkungan alam di sekitar dan siswa paham cara memperbaiki kerusakan yang telah terjadi.

Saat menyelesaikan lembar kerja yang harus didiskusikan bersama teman kelompok, siswa mengerjakannya dengan baik dan saling bertukar pikiran sehingga pertanyaan-pertanyaan 
yang ada pada lembar kerja dapat terselesaikan dengan baik. Siswa dalam kelompoknya saling terbuka dan menerima pendapat yang dikeluar kan oleh anggota kelompok, sehingga tidak ada siswa yang merasa menang sendiri dengan pendapatnya. Selain itu dengan kegiatan field trip terlihat jelas keberanian dan kekompakan antar sesama siswa dalam satu kelompok pada saat melakukan pengamatan. Penerapan metode field trip pada pembelajaran dapat meningkatkan kepedulian siswa terhadap lingkungan sosial maupun alam karena pada saat pengamatan secara langsung siswa dituntut untuk bekerja sama dalam waktu yang telah ditentukan serta dihadapkan dengan hal-hal tidak terduga yang dapat terjadi di lapangan (Yulianti dan Martuti, 2015).

\section{KESIMPULAN}

Ekosistem mangrove Cagar Alam Pulau Dua merupakan salah satu potensi lokal yang dapat dimanfaatkan oleh siswa sebagai sumber belajar pada materi pencemaran lingkungan. Siswa dapat menjelajahi dan mengamati secara langsung keadaan ekosistem mangrove yang masih alami dan tercemar melalui kegiatan field trip.

Hasil penelitian menunjukkan bahwa tidak terdapat perbedaan sikap ilmiah yang signifikan antara kelas eksperimen dengan kelas kontrol. Nilai sikap ilmiah siswa SMA yang belajar menggunakan metode field trip Cagar Alam Pulau Dua sama dengan nilai siswa pada kelas yang belajar dengan metode ceramah dan diskusi. Tanggapan positif diberikan oleh guru dan siswa mengenai pelaksanaan kegiatan field trip mangrove Cagar Alam Pulau Dua pada konsep pencemaran lingkungan.

\section{SARAN}

Berdasarkan penelitian yang telah dilaku kan tentang pengaruh field trip mangrove Cagar Alam Pulau Dua terhadap sikap ilmiah siswa SMA pada konsep pencemaran lingkungan, maka dikemukakan saran berikut ini. Pertama, agar kegiatan field trip ini juga harus diimbangi dengan kesesuaian tujuan belajar yang dibuat oleh guru dengan ketercapaian yang akan dicapai siswa agar kegiatan field trip berjalan efektif. Kedua, pembelajaran dengan kegiatan field trip dapat digunakan untuk meningkatkan keterampilan proses sains karena memberikan kesempatan kepada siswa untuk memperoleh pembelajaran dan pengalaman langsung bagi siswa.

\section{DAFTAR PUSTAKA}

Barlas, M. 2013. Biology Department and Science Education Students' Environ mental Sensitivity, Attitude and Behaviours. International Journal on New Trends in Education and Their Implications. July 2013

Djamarah, S.B dan Zain, A. 2013. Strategi Belajar Mengajar Edisi Revisi. Jakarta: Rineka Cipta

Kementrian Pendidikan dan Kebudayaan. 2014. Materi Pelatihan Guru Implementasi Kurikulum 2013. Jakarta: Badan Pengembangan Sumber Daya Manusia Pendidikan dan Kebudayaan dan Penjaminan Mutu Pendidikan

Kementrian Pendidikan Nasional. 2010. Panduan Pendidikan Karakter di Sekolah Menengah Pertama. Jakarta: Direktorat Jenderal Manajemen Pendidikan dan Menengah.

Komalasari, K. 2011. Pembelajaran Kontekstual Konsep dan Aplikasi. Bandung: PT Refika Aditama.

Natalina, M, Mahadi, I., dan Suzane, A. 2013. Penerapan Model Pembelajaran Inkuiri Terbimbing (guided inquiry) Untuk Meningkatkan Sikap Ilmiah dan Hasil Belajar Biologi Siswa Kelas XI IPA SMA Negeri 5 Pekanbaru Tahun Ajaran 2011/2012. Prosiding Semirata FMIPA Universitas Lampung

Pitafi, A. 2012. Measurement of Scientific Attitude of Secondary School Students in Pakistan. Academic Research Interna tional.2, (2), March 2012

Riyanto, E. 2013.Sikap Ilmiah sebagai Imple mentasi Pendidikan Karakter pada Pem belajaran Sains di Sekolah Dasar. [online]. Tersedia:http//www. ikippgri madiun.ac.id. diakses 6 Januari 2014. 7:50 WIB

Saptono. 2011. Dimensi-Dimensi Pendidikan Karakter. Jakarta: Esensi

Slameto. 2010. Belajar dan Faktor-Faktor yang Mempengaruhinya. Jakarta: Rineka Cipta.

Supriadie dan Darmawan. 2012. Komunikasi Pembelajaran. Jakarta: PT Remaja Rosdakarya. 
Surtikanti, H.K. 2012. Pesona Lingkungan Badan Air Indonesia. Bandung: Rizqi Press.

Suyatno dan Jihat, A. 2013. Menjadi Guru Profesional: Strategi Meningkatkan Kualifikasi dan Kualitas Guru di Era Global. Jakarta: Erlangga.

Takandjandji, M. dan Kwatrina, R.T. 2011. Pengelolaan Cagar Alam Pulau Dua di Provinsi Banten sebagai Ekosistem Bernilai Penting. Jurnal Penelitian Hutan dan Konservasi Alam,8 (2) 1-12.
Wulandari, R. 2016. Metode Kunjungan Lapangan untuk Menanamkan Kepeduli an Terhadap Lingkungan Hidup. Jurnal Pedagogia. Volume. 5, No. 1, Februari 2016.

Yulianti, T dan Martuti, NKT. 2015. Efektivitas Penerapan Metode Field Trip Untuk Meningkatkan Hasil Belajar dan Kepe dulian Siswa Terhadap Lingkungan. Jurnal Pendidikan Matematika dan Sains. Tahun III, No.1, 2015., FMIPA Universitas Negeri Semarang. 